DOI: $10.5277 /$ epe 160205

\author{
MIHAELA MUREŞEANU ${ }^{1}$, ION TRANDAFIR ${ }^{1}$, CRISTINA BĂBEANU $^{1}$, \\ VIORICA PÂRVULESCU ${ }^{2}$, GABRIELA PĂUN ${ }^{3}$
}

\title{
LACCASE IMMOBILIZED ON MESOPOROUS SILICA SUPPORTS AS AN EFFICIENT SYSTEM FOR WASTEWATER BIOREMEDIATION
}

\begin{abstract}
The feasibility of using laccase from Trametes versicolor for degradation of aromatic hydrocarbons has been investigated. In the experiments, benzo[a]pyrene $(\mathrm{BaP})$ was used. Laccase was immobilized onto mesoporous micelle-templated silica such as Santa Barbara Amorphous (SBA-15) and hexagonal mesoporous silica (HMS) as well as corresponding amino-functionalized supports. The best results were obtained for SBA-15 mesoporous silica however the HMS support could be as well considered for this type of application. The reusability of laccase immobilized into both silica supports was tested for five reaction cycles and the conversion reached about $70 \%$ of the initial value.
\end{abstract}

\section{INTRODUCTION}

This work is a part of a study whose ultimate goal is to propose a complete wastewater bioremediation treatment for removal of toxic compounds (e.g. polycyclic aromatic hydrocarbons, phenols, organophosphorous, pesticides, pigments) and of heavy metals with coupling phenol oxidase enzymes and some selective biological chelators anchored at the surface of mesoporous silica supports and packed into fixed bed columns. A mesoporous hybrid silica bio-adsorbent based on a low-molecular weight protein metallothioneine was already tested for selective adsorption of $\mathrm{Cu}(\mathrm{II})$ ions from contaminated water both in batch and in-flow process [1].

${ }^{1}$ Faculty of Mathematics and Natural Sciences, Department of Chemistry, University of Craiova, Craiova, Romania, corresponding author M. Mureşeanu, e-mail: mihaela_mure@yahoo.com

${ }^{2}$ Institute of Physical Chemistry, Romanian Academy of Sciences, Bucharest, Romania.

${ }^{3}$ National Institute of Research and Development for Biological Sciences, Center of Bioanalysis, Bucharest, Romania. 
Phenol oxidases are enzymes that catalyze reaction of dioxygen reduction to water with production of substrate radicals which are non-enzymatically converted to dimmers, oligomers and polymers [2]. Increasing numbers of oxidative biotransformation of phenol oxidases, especially laccases (EC 1.10.3.2), have been extensively reviewed [3-5]. Laccases can be involved in the detoxification of phenols, trichlorophenols, organophosphorous pesticides, azo dyes and, interestingly, PAHs, a class of highly mutagenic and carcinogenic xenobiotics, widely distributed in terrestrial and aquatic environments [6-10].

Thus, using enzymes as decontaminating agents has received great attentions because of their potential to remove pollutants from environment without the harsh side effects associated with many other methods. However, operational stability of native enzymes is rather limited. Therefore, immobilization is very often applied in order to overcome this limitation, as was summarized by Fernández-Fernández et al. [11] allowing one to develop many possible applications, including bioremediation, chemical synthesis, biobleaching of paper pulp, biosensing, textile finishing and wine stabilization.

Laccases have been successfully immobilized on many different types of carriers such as magnetic chitosan microspheres [12], nanoparticles and kaolinite [7], mesostructured siliceous cellular foams [13], mesoporous silica [14], fibrous membranes [15] or titania nanoparticles and titania-functionalized membranes [16]. Among these, the mesostructured sol-gel materials which possess highly ordered structure, with pore sizes similar or larger than most enzyme molecules, showing very high chemical, thermal, mechanical and biological resistance afford preparations with ultrahigh activity $[13,17]$. Mesoporous micelle-templated silica such as Santa Barbara Amorphous (SBA-15) and hexagonal mesoporous silica (HMS) have currently been receiving great attention due to their unique properties of highly controlled and uniform pore size and high values of surface area and pore volume. Despite of the HMS being less ordered than the MCM-41 and SBA-15 materials, they are much easier and straightforward to synthesize due to the use of a cheap and neutral template, i.e. long chain amines, which does not require strongly acidic conditions.

In the present work, laccase from Trametes versicolor was immobilized on SBA-15 and HMS type mesoporous silica and on $\mathrm{NH}_{2}$-functionalized mesoporous silica by either physical adsorption or covalent binding when the supports were activated by cross-linking with glutaraldehyde. To the best of our knowledge, immobilization of laccases has not been carried out yet on HMS mesoporous silica support. The efficiencies of these immobilized laccases on degradation of $\mathrm{BaP}$ in the presence and in the absence of redox mediators as well as the reusability of the catalyst were presented in order to develop detoxification processes of aromatic compounds from contaminated waters. 


\section{EXPERIMENTAL}

Materials. Benzo[a]pyrene (BaP), 2,2'-azino-bis(3-ethylbenzothiazoline-6-sulfonic acid) (ABTS), acetone and acetonitrile were obtained from Sigma. Laccase (E.C.1.10.3.2) from Trametes versicolor was also purchased from Sigma with an activity of 33 I.U./mg protein and used without further purification. Poly(ethylene oxide)-poly(propylene oxide)-poly(ethylene oxide) $\left(\mathrm{EO}_{20} \mathrm{PO}_{70} \mathrm{EO}_{20}\right)$, dodecyl amine (DDA), and tetraethyl orthosilicate (TEOS, 98\%) were obtained from Aldrich.

Synthesis of functionalized silica. SBA-15 material was synthesized as described by Zhao et al. [18], while HMS silica was prepared according to the procedure described by Tanev and Pinnavaia [19].The organic-inorganic hybrid materials were obtained by a post-grafting procedure with 3-aminopropyl-triethoxysilane (APTES) [20]. $\mathrm{The}^{\mathrm{NH}_{2}-}$ -functionalized mesoporous silica were referred as SBA-15- $\mathrm{NH}_{2}$ and $\mathrm{HMS}-\mathrm{NH}_{2}$, respectively.

Immobilization of laccase into mesoporous silica supports. Immobilization of laccase was carried out by either physical adsorption or covalent coupling. In a typical procedure for physical adsorption, $1 \mathrm{~g}$ of support (SBA-15, SBA-15- $\mathrm{NH}_{2}, \mathrm{HMS}$, or HMS- $\mathrm{NH}_{2}$ ) was mixed with $10 \mathrm{~cm}^{3}$ of $0.1 \mathrm{M}$ phosphate buffer $(\mathrm{pH} 7.0)$ in a centrifuge tube. Thereafter, $50 \mathrm{mg}$ laccase in $3 \mathrm{~cm}^{3}$ phosphate buffer were added to the mixture and homogenized under magnetic stirring at $278 \mathrm{~K}$. Acetone $\left(30 \mathrm{~cm}^{3}\right)$ was then added drop wise and the stirring was continued for another $30 \mathrm{~min}$. The solids were isolated by centrifugation and washed several times with buffer until no laccase activity was detected in the washing. The immobilized systems were then lyophilized and stored in dark at $253 \mathrm{~K}$.

In the case of covalent binding, the procedure involves the mixing of 1g SBA-15$-\mathrm{NH}_{2}$ with $25 \mathrm{~cm}^{3}$ of $5 \%$ glutaraldehyde in $0.1 \mathrm{M}$ sodium phosphate buffer ( $\mathrm{pH} 7$ ) for $30 \mathrm{~min}$. Then, the excess of glutaraldehyde was removed during three cycles of centrifugation/washing with $10 \mathrm{~cm}^{3}$ buffer solution each. Enzyme $(50 \mathrm{mg})$ in $13 \mathrm{~cm}^{3}$ of phosphate buffer ( $\mathrm{pH} 7.0)$ was added to the activated solid. The suspension was stirred at $278 \mathrm{~K}$ for $24 \mathrm{~h}$, centrifuged at $3000 \mathrm{rpm}$ for $10 \mathrm{~min}$ to remove the buffer, and washed several times with buffer until no laccase activity was detected in the washing. The solid thus obtained was lyophilized and stored at $253 \mathrm{~K}$ (sample denoted SBA-15- $\mathrm{NH}_{2} \mathrm{cov}$ ).

The concentration of protein in the supernatant was determined by the Bradford procedure [21] using bovine serum albumin as a standard. The amounts of immobilized laccase were evaluated by the thermogravimetric (TG/DTG) method and compared with the results of the Bradford assay.

Characterization of solids. Small-angle X-ray diffraction (XRD) data were acquired on a Bruker diffractometer using $\mathrm{Cu} \mathrm{K} \alpha$ radiation. $\mathrm{N}_{2}$ adsorption-desorption isotherms 
were recorded at $77 \mathrm{~K}$ with a Micromeritics ASAP 2010 instrument. The samples were degassed at $323 \mathrm{~K}$ for $12 \mathrm{~h}$ prior to the adsorption measurements. Specific surface area was calculated by the Brunauer, Emmett and Teller (BET) theory, the mesopore volume was determined by nitrogen adsorption at the end of capillary condensation, and pore size distribution was determined from the desorption branches of the isotherms by Broekhoff and de Boer (BdB) theory. Thermogravimetric analysis was carried out using a Netzsch TG 209C thermobalance.

Measurements of the specific activity and estimation of kinetic parameters. The activities of free and immobilized laccase were determined spectrophotometrically by the rate of oxidation of $1 \mathrm{mM}$ ABTS in $0.1 \mathrm{M}$ acetate buffer $(\mathrm{pH} 4.5)$ at $298 \mathrm{~K}$. The substrate solution was aerated by air bubbling before the addition of $0.01 \mathrm{~cm}^{3}$ of $5 \mathrm{mg} \mathrm{cm} \mathrm{cn}^{-3}$ zyme solution for $3 \mathrm{~cm}^{3}$ reaction mixture. During the process, the increase in absorbance at $424 \mathrm{~nm}$ was measured $\left(\varepsilon=36000 \mathrm{dm}^{3} \cdot \mathrm{mol}^{-1} \cdot \mathrm{cm}^{-1}\right.$ for the oxidation product of ABTS). International unit (IU) of laccase activity was defined as the amount of enzyme required to oxidize $1 \mu \mathrm{mol}$ ABTS per minute.

For the determination of the activity of immobilized laccase, $10 \mathrm{mg}$ of active solids were added to $50 \mathrm{~cm}^{3}$ of $1 \mathrm{mM}$ ABTS in $0.1 \mathrm{M}$ acetate buffer (pH 4.5), which was allowed to circulate through the spectrophotometric cell at $298 \mathrm{~K}$. The activities of the immobilized laccase during the process were determined from the plot of absorbance versus reaction time at $424 \mathrm{~nm}$. The enzymatic activity was expressed in IU/mg of immobilized protein or as relative activity with respect to the activity of the free enzyme.

Kinetic parameters of free and immobilized laccases were determined by using ABTS as substrate in the concentration range of 0.05-2 mM. The Michaelis-Menten kinetic parameters were obtained by the nonlinear regression analysis using Origin 6.0 from the plot of the initial reaction rates versus concentration of substrate, based on the following equation:

$$
v=V_{\max } \frac{[\mathrm{S}]}{K_{m}+[\mathrm{S}]}=k_{\mathrm{cat}}[E]_{0} \frac{[\mathrm{S}]}{K_{m}+[\mathrm{S}]}
$$

where $v\left(\mathrm{mM} \cdot \mathrm{min}^{-1}\right)$ is the reaction rate and $[\mathrm{S}]$ is the substrate concentration. $V_{\max }\left(\mathrm{mM} \cdot \mathrm{min}^{-1}\right)$ is the maximum rate achieved by the biocatalyst. The Michaelis constant $K_{m}(\mathrm{mM})$ is the substrate concentration at which the reaction rate is half of $V_{\max }$. $[E]_{0}$ is the enzyme concentration and the reaction rate constant $k_{\mathrm{cat}}\left(\mathrm{mM} \cdot \mathrm{s}^{-1} \cdot \mathrm{g}^{-1}\right)$ is the maximum number of substrate molecules converted to product per enzyme molecule per second.

All assays were replicated three times. Control samples contained boiled immobilized laccase were used to determine the amount of ABTS absorbed on or reacted with the support. 
Properties of immobilized laccase. Thermal stability of the immobilized enzyme was evaluated by measuring the remaining activities after sample incubation in acetate buffer ( $\mathrm{pH} 4.5$ ) for $1 \mathrm{~h}$ at temperature ranging from $313 \mathrm{~K}$ to $353 \mathrm{~K}$.

The $\mathrm{pH}$-stability was determined by incubating the samples for $1 \mathrm{~h}$ at $298 \mathrm{~K}$ in buffers of varying $\mathrm{pH}$ in the range of 2.0-10.0. $\mathrm{pH}$ of the solution was then adjusted to 4.5 and its activity was measured after equilibration. The residual activity was expressed as a percentage relative to the initial enzyme activity.

Oxidation efficiency of immobilized laccase on BaP. The oxidation treatments were performed in $20 \mathrm{~cm}^{3}$ reaction volumes in amber bottles containing: phosphate buffer ( $\mathrm{pH} 7$ ), $\mathrm{BaP}$ dissolved in acetone to make the final concentration $20 \mu \mathrm{M}$, free or immobilized laccase adjusted to $4 \mathrm{IU} / \mathrm{cm}^{3}$. The impact of ABTS on oxidation of $\mathrm{BaP}$ was determined by its addition to some samples to a final concentration of $1.0 \mathrm{mM}$. The reaction mixture was aerated by air bubbling before the enzyme addition. The reaction bottles were incubated in an orbital shaker at $150 \mathrm{rpm}$ and $318 \mathrm{~K}$. The reaction mixture was then centrifuged at $4000 \mathrm{rpm}$ for $10 \mathrm{~min}$, the supernatant was decanted and then the same volume of acetonitrile was added to inactivate the enzyme and shaken for half an hour to extract the BaP. Control sample for the free laccase was prepared in the same manner but the enzyme was inactivated by boiling for $1 \mathrm{~h}$. For the immobilized enzyme system, the controls contain boiled immobilized laccase onto solid supports for evaluating the sorption of $\mathrm{BaP}$ by the supports. The percentage of aerobically oxidized $\mathrm{BaP}$ was calculated from the difference between the $\mathrm{BaP}$ levels in the experimental assay and the corresponding control. All treatments, including controls, were replicated three times. The biocatalyst recycling was also investigated for the laccase immobilized by physical adsorption into HMS- $\mathrm{NH}_{2}$ support or by covalent coupling onto SBA-15- $\mathrm{NH}_{2}$ by using the same amounts of catalyst and substrate and the previously described procedure.

The separation and quantification of $\mathrm{BaP}$ were achieved by using a Surveyor Thermo Electron HPLC system (Thermo Scientific) comprising a vacuum degasser, Surveyor Plus LCPMPP pump, a Surveyor Plus ASP autosampler, a diode array detector with a $5 \mathrm{~cm}$ flow cell and a Chrom Quest 4.2 software. The Hypersil Green PAH column with $5 \mu \mathrm{m}$ packing $(250 \mathrm{~mm} \times 4.6 \mathrm{~mm}$ i.d.) was used in the analysis. The determinations were made in isocratic conditions, at $283 \mathrm{~K}$ using a mixture of acetonitrile/water $(80: 20 \mathrm{v} / \mathrm{v})$ as the mobile phase. The volume injected was $5 \cdot 10^{-3} \mathrm{~cm}^{3}$ and the flow rate of the mobile phase was $1 \mathrm{~cm}^{3} \cdot \mathrm{min}^{-1}$. The wavelength was set at $275 \mathrm{~nm}$ to integrate the peaks. A good resolution was obtained for $\mathrm{BaP}(2.75 \mathrm{~min})$. The $\mathrm{BaP}$ conversion was calculated as the ratio between the amount of oxidized $\mathrm{BaP}$ and the corresponding control. The calibration curves were constructed in the range of 1-200 ppb. Linearity was achieved and the correlation coefficient was 0.999 . All analyses were performed in triplicate with reproducibility always within $3 \%$. 
Samples of the reaction solution were extracted with $n$-hexane. The extracts were analyzed by the $\mathrm{CG} / \mathrm{MS}$ to identify the oxidation products of BaP. Analysis was performed using a GC/MS (DSQ II Thermo Scientific) equipped with a Thermo TR-5MS $(30 \mathrm{~m} \times 0.25 \mathrm{ID} \times 0.25 \mu \mathrm{m}$ film thickness) capillary column. The GC carrier gas was helium, at the flow rate of $1 \mathrm{~cm}^{3} \cdot \mathrm{min}^{-1}$. The GC temperature program was as follows: $313 \mathrm{~K}$ for $3 \mathrm{~min}$, temperature ramp of $10^{\circ} \mathrm{C} / \mathrm{min}$ to $423 \mathrm{~K}$ and temperature ramp of $15^{\circ} \mathrm{C} / \mathrm{min}$ to $523 \mathrm{~K}, 523 \mathrm{~K}$ for $2 \mathrm{~min}$.

\section{RESULTS AND DISCUSSION}

\subsection{SYNTHESIS AND CHARACTERIZATION OF MESOPOROUS MATERIALS}

SBA-15 and HMS mesoporous silica samples have been synthesised and the amino moiety was grafted thereafter on the support surface by a post-synthesis procedure, due to the interaction of surface hydroxyl groups with the ethoxy groups of APTES. The densities of the functional groups grafted on the silica surface measured by thermogravimetric analysis were 3.1 molecules $/ \mathrm{nm}^{2}$ of pure SBA-15 silica and 4.2 molecules/ $\mathrm{nm}^{2}$ of HMS silica, respectively.
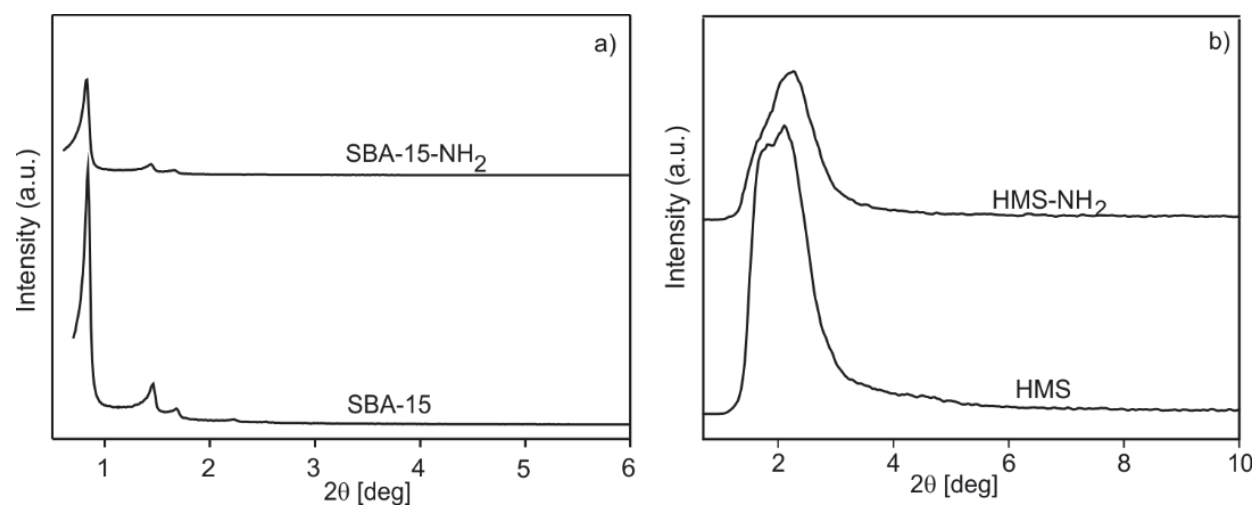

Fig. 1. Powder X-ray diffraction patterns of pure and amino-functionalized silica:

a) SBA-15, b) HMS

The XRD measurements confirmed the SBA-15 structure for both unmodified and grafted samples (Fig. 1a). The SBA-15 material exhibited a strong (100) reflection peak (at $2 \theta=0.7^{\circ}$ ) and smaller (110), (200), (210) diffraction peaks, which are characteristic of a well ordered SBA-15 type material [18]. No significant changes upon amine immobilization were observed, except for the expected decrease in XRD peak intensity, providing evidence that functionalization occurred mainly inside the mesopore channels. 
The XRD patterns of the functionalized HMS silica samples exhibit XRD reflections similar to that of the HMS unmodified support but intensities of the peaks decrease significantly (Fig. 1b). The diffraction peak at $2 \theta=2.5^{\circ}$ may be due to the $d_{100}$ reflection in materials with a short-range hexagonal order. Similar pattern have been reported for ordered mesoporous materials such as HMS [22]. As already noted, these HMS materials do not display the degree of long range order associated with the MCM-41 class of silicates.
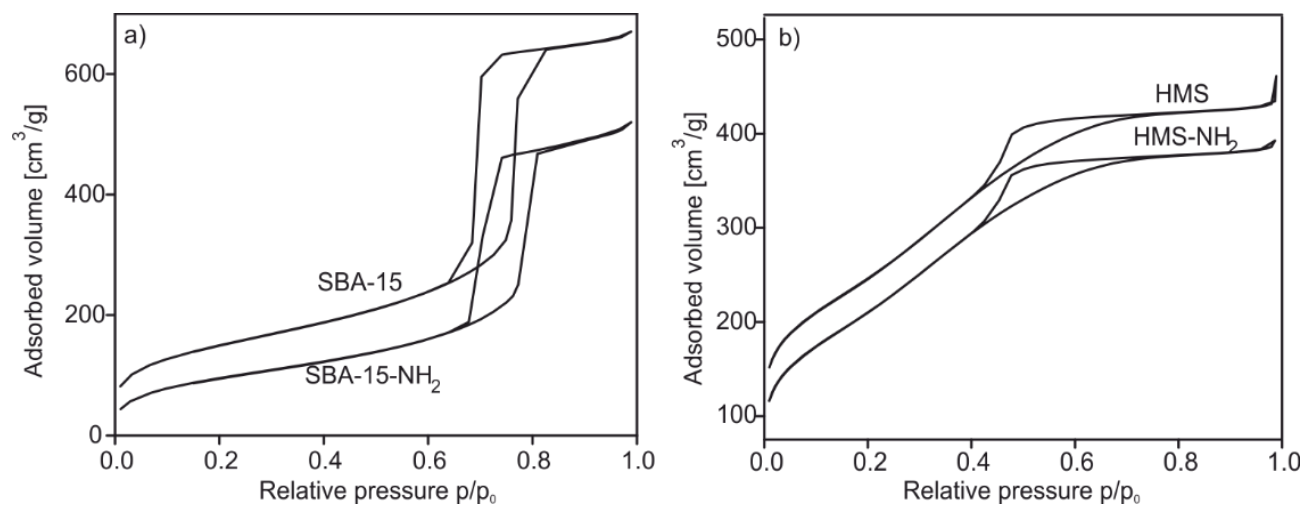

Fig. 2. $\mathrm{N}_{2}$ adsorption-desorption isotherms of pure and amino-functionalized silica: a) SBA-15, b) HMS

All SBA-15 type silica exhibited irreversible type IV adsorption-desorption isotherms (Fig. 2a) with a $\mathrm{H} 1$ hysteresis loop in the relative pressure range from 0.65 to 0.75 , characteristic of materials with $7-8 \mathrm{~nm}$ pore diameter. This result reveals that the uniform mesoporous nature of the material is preserved even though the grafting has occurred. In Table 1, the main textural properties of solids have been listed: specific surface area $S_{\mathrm{BET}}$, mesopore volume $V_{\text {mezo }}$, and pore diameter $D_{\mathrm{BdB}}$ calculated based on the BdB theory.

Table 1

Textural properties of mesoporous silica supports

\begin{tabular}{|l|c|c|c|}
\hline \multicolumn{1}{|c|}{ Material } & $\begin{array}{c}S_{\text {BET }} \\
{\left[\mathrm{m}^{2} \cdot \mathrm{g}^{-1}\right]}\end{array}$ & $\begin{array}{c}\mathrm{V}_{\text {mezo }} \\
{\left[\mathrm{cm}^{3} \cdot \mathrm{g}^{-1}\right]}\end{array}$ & $\begin{array}{c}D_{\text {BdB }} \\
{[\mathrm{nm}]}\end{array}$ \\
\hline HMS & 1029 & 0.79 & 3.5 \\
HMS-NH & 510 & 0.30 & 2.3 \\
SBA-15 & 697 & 1.49 & 8.3 \\
SBA-15-NH 2 & 368 & 0.77 & 7.8 \\
\hline
\end{tabular}

For the functionalized SBA-15 materials, the BET surface and volume were standardized versus pure silica weights. As expected, the BET surface area and the mesopore 
volume strongly decreased after grafting. The nitrogen adsorption isotherm at $77 \mathrm{~K}$ of the calcined HMS material (Fig. 2b) is of type IV, featuring a sharp step corresponding to the filling of the ordered mesopores in the $p / p_{0}$ range of $0.1-0.5$ and a $\mathrm{H} 1$ hysteresis loop at $p / p_{0}$ of 0.5 , being therefore typical of mesoporous materials. The surface area decreased for the HMS- $\mathrm{NH}_{2}$ sample (Table 1). These textural results confirm that the grafted species are located inside the mesopores and not only on the outer surface of the mesoporous silica materials.

\subsection{IMMOBILIZATION AND SPECIFIC ACTIVITY OF LACCASE}

Enzyme immobilization is an effective approach to enhance the enzyme stability. It is well-known that material morphology, surface chemistry, activation and immobilization conditions have an important effect on the enzyme immobilization. Mesoporous materials, ideal carriers for enzymes due to their nanostructures, have been actively developed to immobilize enzymes in the recent years [23]. Previous studies revealed that by immobilization of laccase from $T$. versicolor on various supports an improvement of its catalytic properties such as $\mathrm{pH}$ and temperature, stability or reusability, compared to those of the free laccase was obtained. Moreover, if the support is a highly ordered silica material, a further improvement in the enzyme binding capability and a decrease of the diffusional limitations, as well as a shift of the optimal $\mathrm{pH}$ towards neutrality were achieved [11].

In this study Trametes versicolor laccase was immobilized by adsorption onto SBA-15, HMS, and the corresponding amino-functionalized mesoporous silica in order to obtain an efficient catalyst for the ABTS substrate oxidation. For the SBA-15- $\mathrm{NH}_{2}$ support, the covalent coupling of laccase was also performed. The amount of immobilized enzyme was determined either as equivalent bovine serum albumin by the Bradford assay or as organic mass loss from TG/DTG curves (Table 2). The amount of glutaraldehyde used as a cross-linking agent for the covalent grafting was previously determined from the thermogravimetric analysis assuming total conversion of grafted amine functions and subtracted from the total mass loss in order to obtain the amount of immobilized laccase.

In the case of silica of HMS type, the enzyme immobilization yields are lower than for SBA-15 silica material due to their pore sizes into which the enzyme cannot be incorporated. Therefore, for these materials the immobilization can only take place on the external surface.

The higher yields obtained for the laccase immobilization into the amino-functionalized silica are probably due to the stronger interactions between the enzyme functional groups $\left(-\mathrm{NH}_{2},-\mathrm{COOH},-\mathrm{OH},-\mathrm{SH}\right)$ and that of the support surface. Furthermore, the higher value corresponding to the HMS- $\mathrm{NH}_{2}$ compared to the SBA-15- $\mathrm{NH}_{2}$ can be assigned to the higher density of amino groups ( 4.2 molecules $/ \mathrm{nm}^{2}$ comparatively with 3.1 molecules $/ \mathrm{nm}^{2}$ of pure SBA-15 silica). For enzyme immobilization by physical adsorption, acetone was added to a mixture of the solid support and the buffered enzyme 
solution in order to produce a forced diffusion of the enzyme through the hydrophilic surfaces. This method is more efficient than other adsorption methods due to a better control of protein deposition or agglomeration on solid/liquid interface.

The immobilization yields for laccase immobilization by covalent binding are slightly higher than by physical adsorption (Table 2). These results are in agreement with those reported in literature reviews [6, 7].

Table 2

Amount and enzymatic activity of immobilized laccase onto various supports determined by two different techniques

\begin{tabular}{|c|c|c|c|c|c|}
\hline \multirow[b]{2}{*}{ Material } & \multicolumn{2}{|c|}{ Bound protein [mg/g solid] } & \multirow{2}{*}{$\begin{array}{c}\text { Immobilization } \\
\text { efficiency } \\
{[\%]}\end{array}$} & \multirow{2}{*}{$\begin{array}{c}\text { Enzymatic } \\
\text { activity } \\
\text { [IU/mg protein] }\end{array}$} & \multirow{2}{*}{$\begin{array}{c}\text { Relative } \\
\text { activity } \\
{[\%]}\end{array}$} \\
\hline & $\begin{array}{c}\text { Bradford } \\
\text { method }\end{array}$ & TG & & & \\
\hline SBA-15 & 29.73 & 29.11 & 59.47 & 19.90 & 60.30 \\
\hline SBA-15-NH 2 & 33.67 & 34.12 & 67.33 & 27.75 & 84.10 \\
\hline HMS & 20.47 & 20.03 & 40.93 & 16.73 & 50.68 \\
\hline HMS-NH ${ }_{2}$ & 40.93 & 41.08 & 81.86 & 23.27 & 70.45 \\
\hline SBA-15--NH 2 cov & 37.73 & 41.90 & 75.47 & 28.83 & 87.35 \\
\hline
\end{tabular}

${ }^{a}$ Calculated using the Bradford method to evaluate the protein load.

${ }^{b}$ Determined through the ABTS assay.

${ }^{\mathrm{c}}$ Assuming that the specific activity of the free laccase is $33 \mathrm{IU} / \mathrm{mg}$ protein.

In order to evaluate the efficiency of the immobilized laccase from $T$. versicolor into different mesoporous silica with different techniques, the solids were tested in the ABTS oxidation reaction. The enzymatic activity and relative activity of the immobilized laccase are given in Table 2. The obtained values suggest that the laccase activity strongly depends on the nature of the support surface and the protein loading of the support. Thus, the amino-functionalized silica allows immobilizing a greater amount of protein, and, consequently, the enzymatic activity is higher. Even if for the $\mathrm{HMS}-\mathrm{NH}_{2}$ the yield of immobilization of laccase is higher than that for the SBA-15- $\mathrm{NH}_{2}$, the relative enzymatic activity decreases in accordance with observation of Salis et al. [24]. They suggested that at higher loadings than a maximum value, a decrease of the laccase activity occurs. Nevertheless, the highest relative enzymatic activity was obtained for the laccase covalently bound onto the SBA-15- $\mathrm{NH}_{2}$ support. However, a stress exerted on proteins during the covalent attachment could produce their partial inactivation. Thus, about $87.35 \%$ of the bound enzyme expressed their activity after immobilization (Table 2). For all samples, a decrease of the enzymatic activity compared to that of free enzyme was evidenced. This behavior can be assigned to the change of catalytically active conformation due to the enzyme interactions with the support surfaces. Mass transfer limitation, unfavorable substrate partition, or restrained enzyme flexibility could also affect the enzymatic activity [25]. 
The kinetic parameters of the Michaelis-Menten equation applied to the activity of free and immobilized laccases with good relative activity as a function of ABTS concentration were determined and the results are presented in Table 3.

Table 3

Michaelis-Menten kinetic parameters for free and immobilized laccase into various silica supports

\begin{tabular}{|l|c|c|c|}
\hline \multicolumn{1}{|c|}{ Support } & $\begin{array}{c}V_{\max } \\
{\left[\mathrm{mM} \cdot \mathrm{min}^{-1}\right]}\end{array}$ & $\begin{array}{c}K_{m} \\
{[\mathrm{mM}]}\end{array}$ & $R^{2}$ \\
\hline Free & 0.108 & 0.282 & 0.992 \\
\hline SBA-15-NH $\mathrm{NH}_{2}$ & 0.085 & 3.475 & 0.993 \\
\hline SBA-15-NH $\mathrm{NH}_{2}$ cov & 0.043 & 0.185 & 0.990 \\
\hline HMS-NH & 0.092 & 2.367 & 0.995 \\
\hline
\end{tabular}

Only for SBA-15- $\mathrm{NH}_{2}$ cov sample $K_{m}$ was lower than for free laccase which indicates a higher affinity for the substrate after immobilization. Nevertheless, this lower $K_{m}$ value for covalent immobilized enzyme was counterbalanced by the lowest $V_{\max }$.

For the other samples, the $K_{m}$ values were higher and the $V_{\max }$ values were smaller, compared with that of the free enzyme. This findings prove that immobilization decreased the affinity for the substrate but this negative effect was compensated by the increased stability of the immobilized biocatalysts. The internal and external limitations such as mass transfer resistance, limited accessibility of active sites after immobilization, the conformational changes of the protein molecule and steric hindrance are the major factors that could lead to an increase in $K_{m}$ and a decrease in $V_{\max }$ [16].

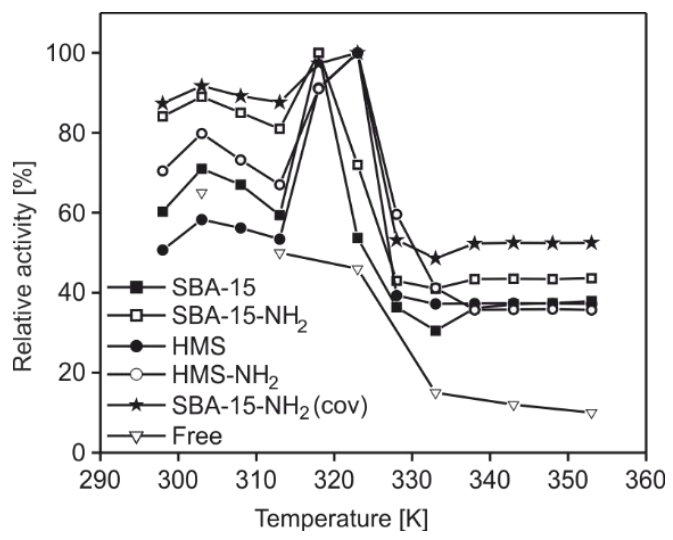

Fig. 3. Effect of temperature on the activity of free and immobilized laccase in various mesoporous silica supports

The effect of temperature on the relative activity of the immobilized enzyme was examined (Fig. 3). The optimal temperature (i.e. the temperature that shows a maximum 
relative activity) for all the immobilized laccases ranged between 318 and $323 \mathrm{~K}$. Laccase immobilized on SBA-15 or HMS mesoporous silica is more stable toward heat denaturation in the $313-353 \mathrm{~K}$ temperature range. Thus, after $1 \mathrm{~h}$ of incubation at $323 \mathrm{~K}$, SBA-15- $\mathrm{NH}_{2}$ cov retained almost $100 \%$ of its initial activity, whereas free laccase retained ca. 45\% (Fig. 3). All immobilized enzymes showed an analogous behavior in the investigated temperature range, after $1 \mathrm{~h}$ incubation. Free laccase is denaturated and lost its activity after exposure at above $323 \mathrm{~K}$, while immobilized laccase into different supports retained between $40 \%$ and $55 \%$ of its initial activity at the same temperature. The temperature required to inactivate laccase immobilized on mesoporous silica was higher than $353 \mathrm{~K}$.

Fig. 4. Effect of $\mathrm{pH}$ on the activity of free and immobilized laccase in various mesoporous silica supports

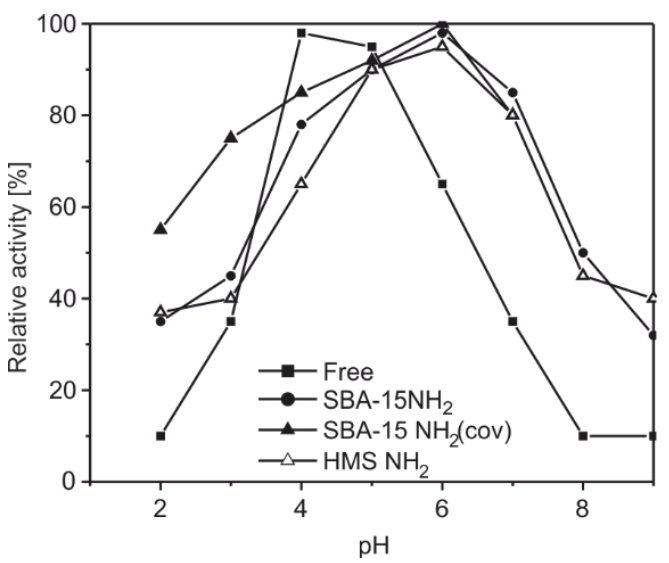

Investigations of $\mathrm{pH}$ effect on activity of free and immobilized laccase showed that activity profile from the bound enzyme is shifted toward neutrality (Fig. 4). The most favorable $\mathrm{pH}$ of all the immobilized laccases was 5.5-6. Incubation of the enzymes in buffers of various $\mathrm{pH}$ indicated that immobilization improved stability of laccase over a wide $\mathrm{pH}$ range (4-7) compared with the free counterpart. At acidic solution ( $\mathrm{pH} 2.0$ ), free laccase almost lost its activity but immobilized laccase retained more than $35 \%$. A similar behavior was observed under alkaline conditions, indicating that the resistance of laccase to acid and basic denaturation was considerably increased after immobilization. The stability of $\mathrm{pH}$ indicated that the mesoporous supports created a more favorable environment for immobilized laccase, which could make this one more applicable to industrial use.

\subsection{OXIDATION EFFICIENCY OF IMMOBILIZED LACCASE ON BaP}

Previous studies $[6,7,15]$ on the oxidation of $\mathrm{BaP}$ with free and immobilized laccase showed a considerable increase of the conversion after addition of ABTS to the reaction mixture. The role of ABTS is to mediate the oxidation of $\mathrm{BaP}$ by laccase $[6,7]$. 
In our study, the reactions of oxidation of $\mathrm{BaP}$ were investigated using free and five immobilized laccases, in absence or presence of ABTS mediator. The highest $\mathrm{BaP}$ conversion among the immobilized laccases was obtained for the SBA-15- $\mathrm{NH}_{2}$ cov sample (Fig. 5). These results are in agreement with the above mentioned laccase activities for the ABTS oxidation. The conversion yields of biocatalysts based on HMS supports (40\% for HMS- $\mathrm{NH}_{2}$ and $28 \%$ for HMS, respectively) were lower than those for SBA-15 (52\% for SBA-15- $\mathrm{NH}_{2}$ and $35 \%$ for SBA-15, respectively) but their values are however considerable and correlated with the amount of immobilized protein.

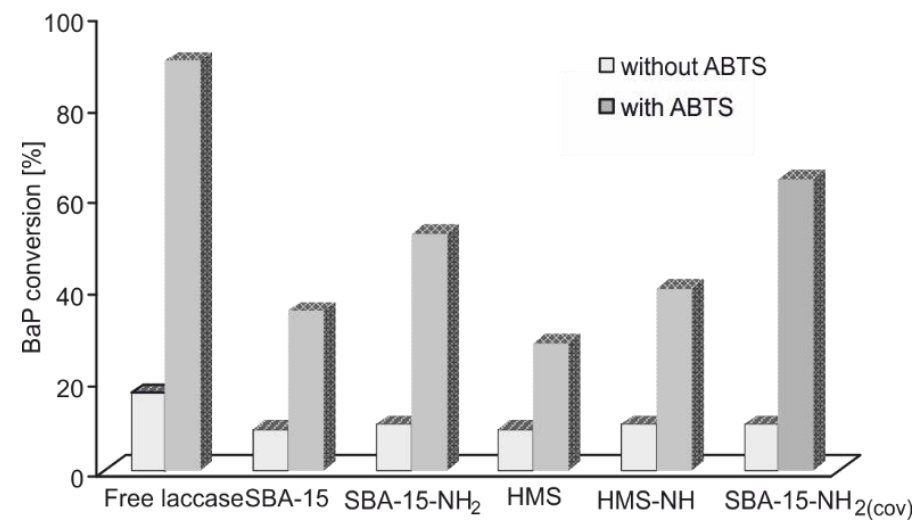

Fig. 5. Oxidation of benzo[a]pyrene with free and immobilized laccases; $318 \mathrm{~K}, 50 \mathrm{rpm} ; \mathrm{pH}$ 7, concentration of $\mathrm{BaP} 20 \mu \mathrm{M}$

The metabolites of the oxidation of $\mathrm{BaP}$ were identified after their extraction from the reaction mixture in $n$-hexane using GC/MS analysis. After $48 \mathrm{~h}$ of oxidation, the $\mathrm{BaP}$ was stoichiometrically converted to its quinone derivatives. The identified metabolites were: 1,6-benzo[a]pyrene quinone (1,6-BaQ), 3,6-benzo[a]pyrene quinone (3,6-BaQ), 6,12-benzo[a]pyrene quinone $(6,12-\mathrm{BaQ})$. These metabolites were also observed in a previous study [7]. Further studies will be performed to establish the isomer ratio and the oxidation mechanism.

Due to the possibility to recycle the immobilized enzyme, the area of their technological applications can be extended. Therefore, the effect of its reuse as a catalyst in several oxidation of $\mathrm{BaP}$ reaction cycles was investigated. The HMS- $\mathrm{NH}_{2}$ and SBA-15$-\mathrm{NH}_{2}$ cov samples were used as biocatalyst. The $\mathrm{BaP}$ conversion values after repeated use of immobilized laccase in the oxidation of BaP mediated by ABTS are shown in Fig. 6 . After the 5th reaction cycle the conversion reached about $58 \%$ for the SBA-15$\mathrm{NH}_{2}$ cov sample and $25 \%$ for $\mathrm{HMS}-\mathrm{NH}_{2}$ sample, respectively. This means that after the fifth cycle, the oxidative activity of the biocatalysts comparatively with their initial activity was $85 \%$ for SBA-15- $\mathrm{NH}_{2}$ cov and $63 \%$ for $\mathrm{HMS}-\mathrm{NH}_{2}$ sample, respectively. It is clear that the biocatalyst obtained by covalent coupling of laccase to the mesoporous 
support was more stable toward the leaching effect during the multiple recycling. We intend to immobilize laccase by covalent coupling into the HMS- $\mathrm{NH}_{2}$ support, in order to further compare the reusability of laccase immobilized into the same support but by different methods.
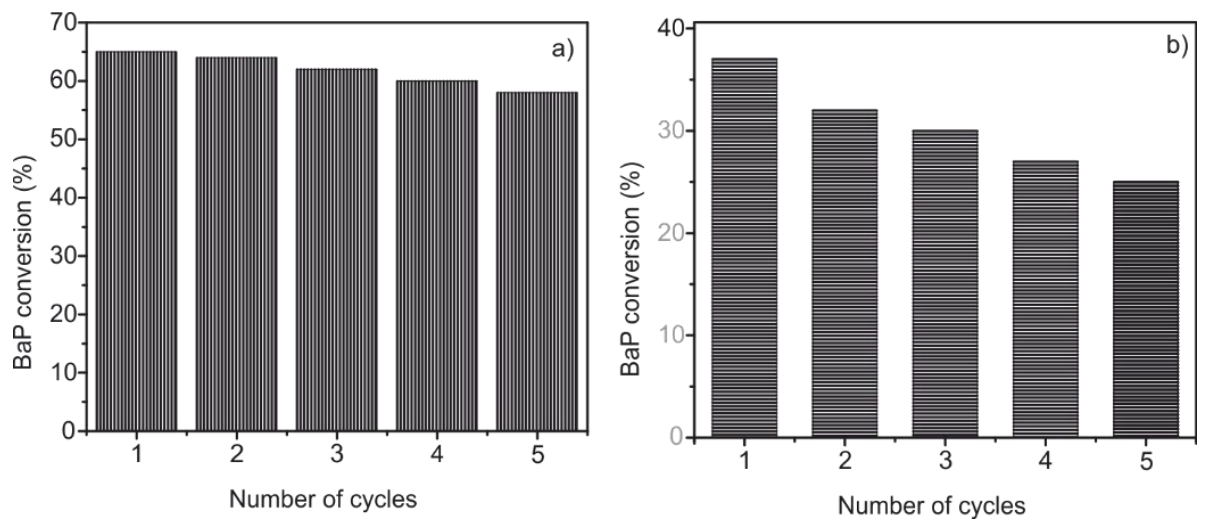

Fig. 6. Effect of recycling immobilized laccase on oxidation of BaP: a) SBA-15-NH2 cov, b) $\mathrm{HMS}-\mathrm{NH}_{2}, 318 \mathrm{~K}, 50 \mathrm{rpm}, \mathrm{pH} 7$, concentration of $\mathrm{BaP} 20 \mu \mathrm{M}$

\section{CONCLUSIONS}

Laccase from Trametes versicolor immobilized on ordered HMS or SBA-15 mesoporous silica supports by physical adsorption or chemical bonding could be used for effective PAHs remediation. The HMS silica support presented smaller, however considerable activities for the ABTS oxidation as well as for the conversion of benzo[a]pyrene into oxidation products than SBA-15 silica. Considering that this support could be easily synthesized from cheaper reagents, it could be used as an efficient material for laccase immobilization and its application in biodegradation processes. This highly ordered inorganic mesoporous supports exhibit several benefits such as: the reproducibility of the material through a standardized synthesis procedure, easiness of their surface modification in order to allow the enzyme immobilization, and high stability and reusability of the obtained biocatalysts.

\section{ACKNOWLEDGMENTS}

This work was partially supported by the grant number $1 \mathrm{C} / 2014$, awarded in the internal grant competition of the University of Craiova. 


\section{REFERENCES}

[1] Mureseanu M., Cioatera N., Trandafir I., Georgescu I., Fajula F., Galarneau A., Selective $\mathrm{Cu}^{2+}$ adsorption and recovery from contaminated water using mesoporous hybrid silica bioadsorbents, Micropor. Mesopor. Mat., 2011, 146 (1-3), 141.

[2] BuRTON S.G., Laccases and phenol oxidases in organic synthesis. A review, Curr. Org. Chem., 2003, 7 (13), 1317.

[3] Yang S., Hai F.I., NGhiem L.D., Price W.E., Roddick F., Moreira M.T., Magram S.F., Understanding the factors controlling the removal of trace organic contaminants by white-rot fungi and their lignin modifying enzymes. A critical review, Bioresour. Technol., 2013, 141, 97.

[4] Witayakran S., RagausKas A.J., Synthetic applications of laccase in green chemistry, Adv. Synth. Catal., 2009, 351, 1187.

[5] Duran N., Rosa M.A., D’Annibale A., Gianfreda L., Applications of laccase and tyrosinases (phenoloxidases) immobilized on different supports: a review, Enzyme Microb. Technol., 2002, 31, 907.

[6] Dodor D.E., Hwang H.-M., Ekunwe S.I.N., Oxidation of anthracene and benzo[a]pyrene by immobilized laccase from Trametes versicolor, Enzyme Microb. Technol., 2004, 35 (2-3), 210.

[7] Hu X., Zhao X., Hwang H.-M., Comparative study of immobilized Trametes versicolor laccase on nanoparticles and kaolinite, Chemosphere, 2007, 66 (9), 1618.

[8] Mohammadi A., NASERneJAD B., Enzymatic degradation of anthracene by the white rot fungus Phanerochaete chrysosporium immobilized on sugarcane bagasse, J. Hazard. Mater., 2009, 161 (1), 534.

[9] Riva S., Laccases. Blue enzymes for green chemistry, Trends Biotechnol., 2006, 24, 219.

[10] Rodriguez COUTO S., TOCA-HERRERA J.L., Industrial and biotechnological applications of laccases. A review, Biotechnol. Adv., 2006, 24, 500.

[11] FERnÁndeZ-FERnÁNDEZ M., SANROMÁn Á.M., Moldes D., Recent developments and applications of immobilized laccase, Biotechnol. Adv., 2013, 31, 1808.

[12] JiAng D.-S., Long S.-Y., HuAng J., XIAO H.-Y., ZhOU J.-Y., Immobilization of Pycnoporus sanguineus laccase on magnetic chitosan microspheres, Biochem. Eng. J., 2005, 25 (1), 15.

[13] ReKuĆ A., BRYJAK J., SZYMAŃSKa K., JARZĘBSKI A.B., Laccase immobilization on mesostructured cellular foams affords preparations with ultra high activity, Process. Biochem., 2009, 44 (2), 191.

[14] NAIR R.R., DemARChe P., AGATHOS S.N., Formulation and characterization of immobilized laccase biocatalyst and application to eliminate organic micropollutants in wastewater, New Biotechnol., 2012, $30(6), 814$.

[15] NiU J., DAI Y., GUO H., XU J., SHEN Z., Adsorption and transformation of PAHs from water by laccaseloading spider-type reactor, J. Hazard. Mater., 2013, 248-249, 254.

[16] Hou J., DONG G., Ye Y., CHEN V., Laccase immobilization on titania nanoparticles and titania-functionalized membranes, J. Membrane Sci., 2014, 452, 229.

[17] Szymańska K., Bryjak J., Mrowiec-Bialoń J., JarZęBSKi A.B., Application and properties of siliceous mesostructured cellular foams as enzymes carriers to obtain efficient biocatalysts, Micropor. Mesopor. Mater., 2007, 99, 167.

[18] Zhao D., Feng J., Huo Q., Melosh N., Fredrickson G.H., Chmelka B.F., Stucky G.D., Triblock copolymer syntheses of mesoporous silica with periodic 50 to 300 angstrom pores, Science, 1998, 279 (5350), 548.

[19] TANev P.T., Pinavaia T.J., Mesoporous silica molecular sieves prepared by ionic and neutral surfactant templating. A comparison of physical properties, Chem. Mater., 1996, 8 (8), 2068.

[20] Martin T., Galarneau A., Brunel D., Izard V., Hulea V., Blanc A.C., Abramson S., Di Renzo F., FaJUla F., Towards total hydrophobisation of MCM-41 type silica surface, Stud. Surf. Sci. Catal., 2001, 135, 4621. 
[21] BRADFORD M.M., A rapid and sensitive method for the quantitation of microgram quantities of protein utilizing the principle of protein-dye binding, Anal. Biochem., 1976, 72 (1-2), 248.

[22] Pauly T.R., Pinnavaia T.J., Pore size modification of mesoporous HMS molecular sieve silicas with wormhole framework structures, Chem. Mater., 2001, 13 (3), 987.

[23] ShaKeel A.A., QAyYum H., Potential applications of enzymes immobilized on/in nano materials. A review, Biotechn. Adv., 2012, 30, 512.

[24] Salis A., Pisano M., Monduzzi M., Solinas V., SAnjust E., Laccase from Pleurotus sajor-caju on functionalised SBA-15 mesoporous silica. Immobilisation and use for the oxidation of phenolic compounds, J. Mol. Catal. B: Enzym., 2009, 58 (1-4), 175.

[25] CaO L., Immobilised enzymes: science or art?, Curr. Opin. Chem. Biol., 2005, 9 (2), 217. 